\title{
In vivo and in vitro suppression by leptin of glucose-stimulated insulin hypersecretion in high glucose-fed rats
}

\author{
Glenda Widdup, Janet M Bryson, Dorota Pawlak, Jenny L Phuyal, Gareth S Denyer and Ian D Caterson \\ Human Nutrition Unit, Department of Biochemistry, University of Sydney, Sydney, New South Wales 2006, Australia \\ (Correspondence should be addressed to J Bryson; Email: j.bryson@biochem.usyd.edu.au)
}

\begin{abstract}
Objectives: Chronic feeding to rats of high glycaemic index (GI) diets results in the hypersecretion of insulin in response to an i.v. glucose load. The first aim of this study was to see if this exaggerated insulin response was accompanied by a hypersensitivity to glucose stimulation in isolated islets in vitro. The second aim was to see if the adipocyte factor, leptin, was able to alter insulin secretion in this model both in vivo and in vitro.

Design and methods: Rats were fed for 6 weeks either a high GI diet in which the carbohydrate component was mostly glucose (GLUC diet) or a low GI diet containing mostly amylose (AMOSE diet). Rats then underwent an i.v. glucose tolerance test (ivGTT) $(1 \mathrm{~g} / \mathrm{kg})$ with and without a prior infusion of leptin $(133 \mu \mathrm{g} / \mathrm{kg}$ per h). Islets were then isolated from these rats and basal and glucose-stimulated insulin secretion (GSIS) measured in both the absence and presence $(100 \mathrm{ng} / \mathrm{ml})$ of leptin.

Results and conclusions: Peak insulin response during the ivGTT was 3-fold greater in GLUC rats $(P<0.001)$. Leptin had no effect on AMOSE rat insulin response but lowered the GLUC rat response to AMOSE rat levels. In vitro, basal insulin secretion was 4 -fold greater in GLUC rats $(P<0.05)$. At $20 \mathrm{mmol} / \mathrm{l}$ glucose, there was no further increase in insulin secretion in GLUC rats but a 2-fold increase in AMOSE rats. Leptin had no effect on basal insulin secretion or GSIS in AMOSE rats but reduced basal insulin secretion and GSIS in GLUC rats. These results show insulin hypersecretion in high GI-fed rats may be reduced by leptin.
\end{abstract}

European Journal of Endocrinology 143 431-437

\section{Introduction}

Dietary carbohydrate consists of many polysaccharides which differ in their rate of digestion and in their effect on postprandial blood glucose levels (1). Long-term feeding to rodents of diets in which the carbohydrate component consists mainly of rapidly absorbed, high glycaemic index (GI) starches causes hypersecretion of insulin in response to an acute glucose challenge (2), suggesting an increased demand for insulin to facilitate peripheral glucose utilisation. However, although tissuespecific dietary-induced changes in insulin sensitivity have been reported in individual tissues in rodent studies (3-5), euglycaemic, hyperinsulinaemic clamp studies have shown no overall whole body change in peripheral glucose uptake in humans (6) or rodents (7) fed these high GI starches. This suggests that the hypersecretion of the $\beta$-cell in response to glucose is due to dietary-induced changes in islet metabolism rather than increased peripheral insulin resistance.

Recently it has been shown that receptors for leptin, the adipocyte factor involved in the regulation of food intake, are present in the $\beta$-cell $(8-11)$. Leptin at physiological doses has been shown to inhibit both basal and glucose-stimulated insulin secretion (GSIS) in vitro $(8,10-13)$, although this has not been found in all studies $(11,14,15)$. In other studies, both acute and chronic leptin administration have been shown to lower circulating insulin levels in vivo (16-18).

The primary aim of this study was to see if the hypersecretion of insulin in response to a glucose challenge in vivo in rodents fed a high GI diet was accompanied by a hypersensitivity to glucose stimulation in isolated islets in vitro. The second aim was to see if exposure to leptin was able to alter this response both in vivo and in vitro.

\section{Animals and methods}

\section{Animals}

Specific pathogen-free male Wistar rats were purchased from the Scientific Research Centre, Perth, WA, Australia, at 6 weeks of age and weighed $180 \pm 2 \mathrm{~g}$ (s.E.M.) at the commencement of the study. The rats were housed five to a cage in the Biochemistry Animal House, University of Sydney. Animals were maintained 
Table 1 Composition of low GI (AMOSE) and high GI (GLUC) diets fed to rats for 6 weeks. Rats were meal fed twice daily $(11.5 \mathrm{~g} / \mathrm{meal})$.

\begin{tabular}{lrr}
\hline Component & $\begin{array}{c}\text { AMOSE diet } \\
\text { (g/kg diet) }\end{array}$ & $\begin{array}{c}\text { GLUC diet } \\
\text { (g/kg diet) }\end{array}$ \\
\hline Casein & 200 & 200 \\
Gelatine & 19 & 19 \\
DL-Methionine & 2 & 2 \\
Mineral mix & 67 & 67 \\
Vitamin mix & 13 & 13 \\
Glucose & 0 & 514 \\
Hi Maize flour (60\% amylose/40\% amylopectin) & 514 & 0 \\
Sucrose & 85 & 85 \\
Unprocessed bran & 50 & 50 \\
Mono-saturated vegetable oil & 25 & 25 \\
Polyunsaturated sunflower oil & 25 & 25 \\
Energy content (kJ/g) & 15 & 15 \\
\hline
\end{tabular}

at $22{ }^{\circ} \mathrm{C}$ on a $12 \mathrm{~h}$ light: $12 \mathrm{~h}$ darkness cycle (lights on from 0600 to $1800 \mathrm{~h}$ ). Approval for the study was obtained from the Sydney University Animal Ethics committee.

\section{Diets}

Upon arrival the rats were randomly divided into two groups to be fed either the amylose diet (AMOSE) or the glucose diet (GLUC), the compositions of which are described in Table 1 . Both diets contained 65\% carbohydrate (55\% starch or glucose; $10 \%$ sucrose), $22 \%$ protein and $11 \%$ fat as a percentage of total energy. The diets were prepared weekly and $11.5 \mathrm{~g}$ per rat were given to the animals in an unpelleted form, twice daily. Rats were maintained on the diets for 6 weeks and weighed weekly to monitor weight gain.

\section{i.v. glucose tolerance test (ivGTT)}

After 6 weeks on the diet, silastic cannulae were inserted into the left and right jugular veins under anaesthesia for infusion of glucose and leptin and for blood sampling. The rats were allowed to recover from surgery for 3-4 days in individual cages and were then fasted overnight before the ivGTT. After a baseline blood sample was taken, leptin-treated rats were given a bolus of recombinant mouse leptin (Amgen, Thousand Oaks, CA, USA) $(500 \mu \mathrm{g} / \mathrm{kg})$ followed by a continuous infusion of leptin $(133 \mu \mathrm{g} / \mathrm{kg}$ per h) in $0.9 \% \mathrm{w} / \mathrm{v} \mathrm{NaCl}$ for $1 \mathrm{~h}$. This protocol was chosen as it has been used in other rat studies to increase plasma leptin levels to supraphysiological levels and to have an effect on insulin sensitivity during euglycaemic hyperinsulinaemic clamp studies (18). Control rats received vehicle only. A further baseline blood sample was taken and all rats were then given an i.v. bolus of $50 \%$ glucose $(1 \mathrm{~g} / \mathrm{kg})$ and blood samples taken at various time points over the next $60 \mathrm{~min}$.

\section{Isolation of the islets of Langerhans and incubation with glucose and leptin}

Rats were given 2 days to recover from the ivGTT and were then killed in the fed state under sodium pentobarbitone anaesthesia. Islets were isolated by collagenase digestion (19). For each incubation, 20 islets were handpicked and preincubated in $2 \mathrm{mmol} / \mathrm{l}$ glucose at $4{ }^{\circ} \mathrm{C}$ for $15 \mathrm{~min}$. The 20 islets were further incubated in $1.0 \mathrm{ml}$ Krebs-Ringer bicarbonate buffer supplemented with 3\% fatty acid-free BSA containing either 5 or $20 \mathrm{mmol} / \mathrm{l}$ glucose, with or without leptin $(100 \mathrm{ng} / \mathrm{ml})$ for $1 \mathrm{~h}$ at $37^{\circ} \mathrm{C}$. Incubation medium was stored at $-20{ }^{\circ} \mathrm{C}$ for subsequent insulin assay. Results are expressed as nanograms insulin per millilitre incubation medium, which represents the insulin secreted by 20 islets in $1 \mathrm{~h}$. Unused islets were frozen for measurement of triglyceride (TG) content.

\section{Serum analyses}

Serum leptin was measured using a commercial RIA kit (Linco Research, St Louis, MO, USA). Intraassay variation was $4.2 \%$ and interassay variation less than $6.0 \%$. Serum insulin was measured by RIA using rat insulin standards and anti-rat insulin first antibody (Linco). Intraassay variation was $6.5 \%$ and interassay variation less than $8.0 \%$. Serum glucose was measured by a glucose oxidase/peroxidase method with 4-amino-antipyrine as the dye, and serum TG and non-esterified fatty acids (NEFA) by commercial in vitro enzymatic colorimetric assays (Boehringer Mannheim, Mannheim, Germany and WAKO, Osaka, Japan).

\section{Islet TG assay}

TGs were extracted from the islets by chloroform/ methanol extraction following sonication of the islets for $60 \mathrm{~s}$. TG content was measured by a colorimetric enzymatic procedure as for serum analyses. 
Table 2 Differences in body weight, pancreas weight and serum hormone and metabolite levels between groups of rats fed either a high glucose diet (GLUC) or high amylose diet (AMOSE) for 6 weeks. Results are means \pm S.E.M.. The number in each group is in parentheses.

\begin{tabular}{lcc}
\hline & GLUC & AMOSE \\
\hline Final body weight $(\mathrm{g})$ & $340 \pm 4(23)$ & $305 \pm 3(26)^{\mathrm{a}}$ \\
Weight of pancreas $(\mathrm{g})$ & $1.5 \pm 0.1(10)$ & $1.2 \pm 0.1(10)^{\mathrm{a}}$ \\
Islet TG content $(\mu \mathrm{mol} / \mathrm{g}$ wet weight) & $33.7 \pm 5.0(12)$ & $8.3 \pm 1.9(12)^{\mathrm{b}}$ \\
Fed plasma levels (no. per group) & $(6)$ & $(12)$ \\
$\quad$ Glucose $(\mathrm{mmol} / \mathrm{l})$ & $9.31 \pm 0.76$ & $10.40 \pm 0.35$ \\
Insulin $(\mathrm{ng} / \mathrm{ml})$ & $5.19 \pm 0.65$ & $5.48 \pm 0.65$ \\
Leptin $(\mathrm{ng} / \mathrm{ml})$ & $5.19 \pm 1.09$ & $3.28 \pm 0.43^{\mathrm{a}}$ \\
TGs $(\mathrm{mmol} / \mathrm{l})$ & $1.45 \pm 0.15$ & $1.08 \pm 0.11^{\mathrm{a}}$ \\
NEFAs $(\mathrm{mmol} / \mathrm{l})$ & $0.49 \pm 0.10$ & $0.28 \pm 0.04^{\mathrm{a}}$ \\
\hline a & &
\end{tabular}

\section{Statistics}

All results are given as means \pm S.E.M. Differences between groups and the effects of leptin were examined using Student's $t$-test or one-way ANOVA using the Statview IV statistical package (Abacus Concepts, Berkeley, CA, USA).

\section{Results}

Differences in anthropometric and metabolic parameters after 6 weeks of feeding are summarised in Table 2. GLUC rats gained weight more quickly than AMOSE rats and were significantly heavier by 3 weeks. Both the weight of the pancreas and the TG content of the islets were significantly higher in GLUC rats. There was no difference in plasma glucose and insulin levels but GLUC rats had higher leptin, reflecting the higher body weight, as well as higher TG and NEFA levels.

Glucose responses to the ivGTT are shown in Fig. 1. There was no difference in the basal glucose level, the peak glucose response and the area under the curve (AUC) between GLUC rats and AMOSE rats (Table 3). Leptin infusion for $1 \mathrm{~h}$ before the ivGTT had no effect on any of these parameters. Although basal insulin levels were the same, there was a significantly greater insulin response to the glucose load in GLUC rats (Fig. 2) with a higher peak value and an increase in the AUC (Table 3). Prior leptin infusion had no effect on the insulin response in AMOSE rats. However, there was a dramatic decrease in the size of the insulin response in GLUC rats such that there was no difference between AMOSE rats and the leptin-treated GLUC rats.

Islets isolated from GLUC rats had a 4-fold higher insulin secretion rate than those from AMOSE rats after incubation in basal $(5 \mathrm{mmol} / \mathrm{l})$ glucose (Fig. 3) $(P<0.05)$. Whereas increasing the glucose concentration to $20 \mathrm{mmol} / \mathrm{l}$ caused a 2 -fold increase in insulin secretion in the AMOSE group $(P<0.05)$, there was no change in the already-elevated insulin secretion from GLUC rat islets. The addition of leptin to the incubation medium

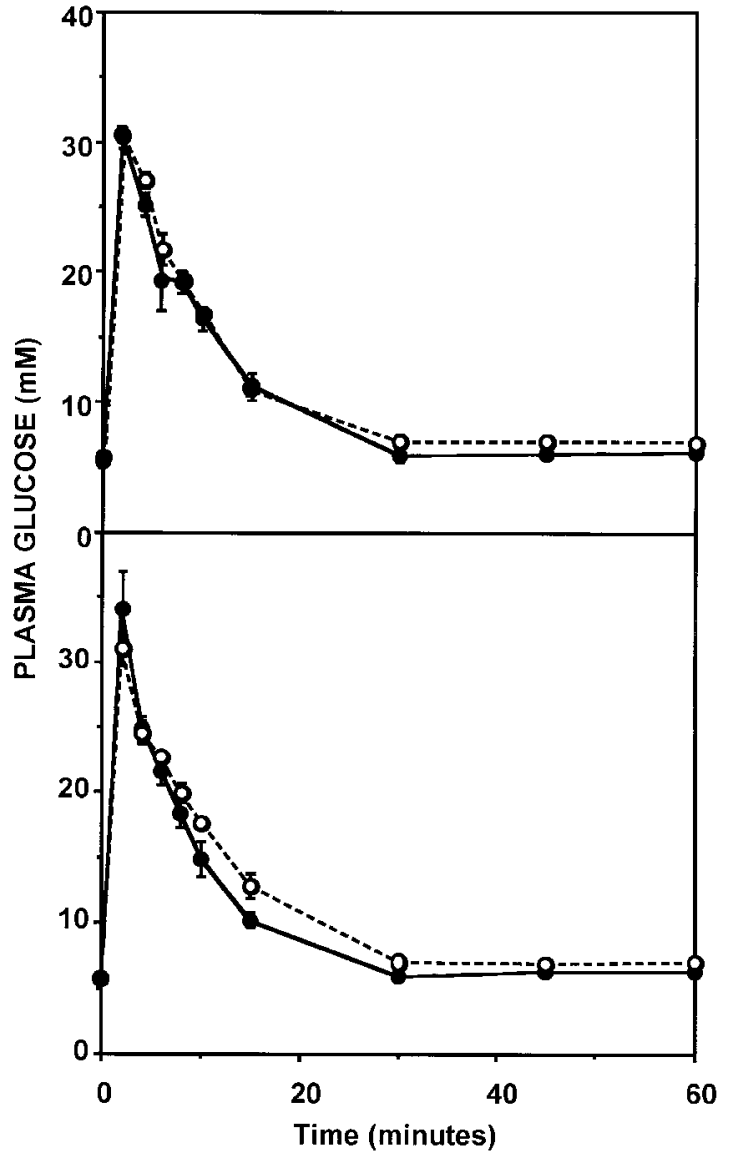

Figure 1 Plasma glucose response to an i.v. glucose load $(1 \mathrm{~g} / \mathrm{kg})$ in GLUC rats (upper panel) and AMOSE rats (lower panel) with (O) and without $(0)$ prior leptin infusion. Treated rats were given a bolus of leptin $(500 \mu \mathrm{g} / \mathrm{kg})$ followed by a continuous infusion of leptin $(133 \mu \mathrm{g} / \mathrm{kg}$ per h) in $0.9 \% \mathrm{w} / \mathrm{v}$ saline for $1 \mathrm{~h}$. Untreated animals received vehicle only. Each point is the mean \pm S.E.M. for at least six rats. Results are summarised in Table 3. 
Table 3 Basal plasma hormone and metabolite levels and the glucose and insulin responses to an ivGTT (1 g/kg) in both AMOSE- and GLUC-fed rats with and without prior exposure to leptin. Leptin was given as a bolus of $500 \mu \mathrm{g} / \mathrm{kg}$ followed by a continuous infusion of leptin $(133 \mu \mathrm{g} / \mathrm{kg})$ for $1 \mathrm{~h}$. Control animals received vehicle only. Results are means \pm S.E.M.

\begin{tabular}{|c|c|c|c|c|}
\hline & \multicolumn{2}{|c|}{ GLUC } & \multicolumn{2}{|c|}{ AMOSE } \\
\hline & No leptin $(n=8)$ & Leptin $(n=5)$ & No leptin $(n=8)$ & Leptin $(n=6)$ \\
\hline \multicolumn{5}{|l|}{ Basal levels } \\
\hline Glucose (mmol/l) & $5.4 \pm 0.3$ & $5.9 \pm 0.2$ & $5.7 \pm 0.3$ & $5.7 \pm 0.1$ \\
\hline Insulin (ng/ml) & $2.0 \pm 0.2$ & $1.7 \pm 0.3^{\mathrm{a}}$ & $1.6 \pm 0.3$ & $0.9 \pm 0.2^{\mathrm{a}, \mathrm{c}}$ \\
\hline Leptin (ng/ml) & $2.8 \pm 0.4$ & $47.0 \pm 2.1^{\mathrm{b}}$ & $2.3 \pm 0.4$ & $64.3 \pm 5.7^{b}$ \\
\hline TGs (mmol/l) & $1.8 \pm 0.2$ & $0.8 \pm 0.3^{\mathrm{a}}$ & $1.2 \pm 0.2^{c}$ & $0.9 \pm 0.2$ \\
\hline \multicolumn{5}{|l|}{ Peak levels } \\
\hline Glucose (mmol/l) & $30.3 \pm 0.8$ & $30.6 \pm 0.6$ & $34.2 \pm 2.7$ & $30.9 \pm 1.3$ \\
\hline Insulin (ng/ml) & $65.4 \pm 10.5$ & $19.7 \pm 4.0^{b}$ & $14.3 \pm 1.8^{d}$ & $13.6 \pm 1.2$ \\
\hline \multicolumn{5}{|l|}{ AUC } \\
\hline Glucose $(\mathrm{mmol} / \mathrm{l} \times \mathrm{h})$ & $590 \pm 26$ & $633 \pm 12$ & $587 \pm 20$ & $653 \pm 11$ \\
\hline Insulin $(\mathrm{ng} / \mathrm{ml} \times \mathrm{h})$ & $707 \pm 163$ & $298 \pm 48^{b}$ & $200 \pm 30^{d}$ & $214 \pm 26$ \\
\hline
\end{tabular}

${ }^{\mathrm{a}} P<0.05,{ }^{\mathrm{b}} P<0.01$ for effect of leptin treatment. ${ }^{\mathrm{c}} P<0.05,{ }^{\mathrm{d}} P<0.01$ for differences between GLUC and AMOSE.

had no effect on the insulin secretion rate at either glucose concentration in the AMOSE rats. However, in islets from GLUC rats, leptin caused a non-significant decrease in insulin secretion at basal glucose, with greater attenuation of insulin secretion being seen in the presence of $20 \mathrm{mmol} / \mathrm{l}$ glucose $(P<0.05)$, such that there was no difference in secretion between islets from GLUC and AMOSE rats.

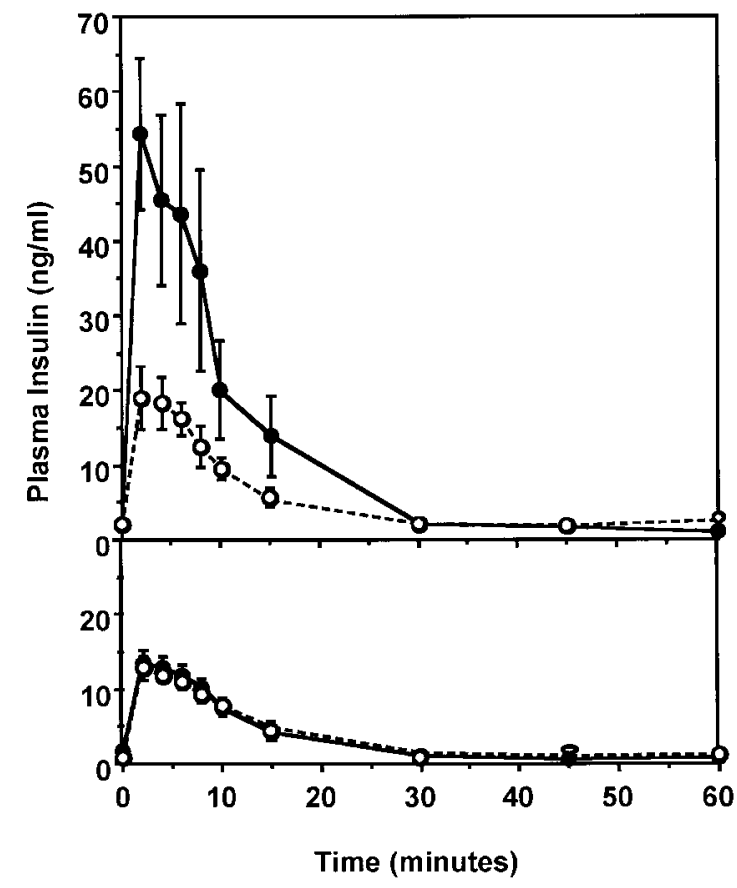

Figure 2 Plasma insulin response to an i.v. glucose load $(1 \mathrm{~g} / \mathrm{kg})$ in GLUC rats (upper panel) and AMOSE rats (lower panel) with (O) and without $(\bullet)$ prior leptin infusion. Treated rats were given a bolus of leptin $(500 \mu \mathrm{g} / \mathrm{kg})$ followed by a continuous infusion of leptin $(133 \mu \mathrm{g} / \mathrm{kg}$ per h) in $0.9 \% \mathrm{w} / \mathrm{v}$ saline for $1 \mathrm{~h}$. Untreated animals received vehicle only. Each point is the mean \pm S.E.M. for at least six rats. Results are summarised in Table 3.

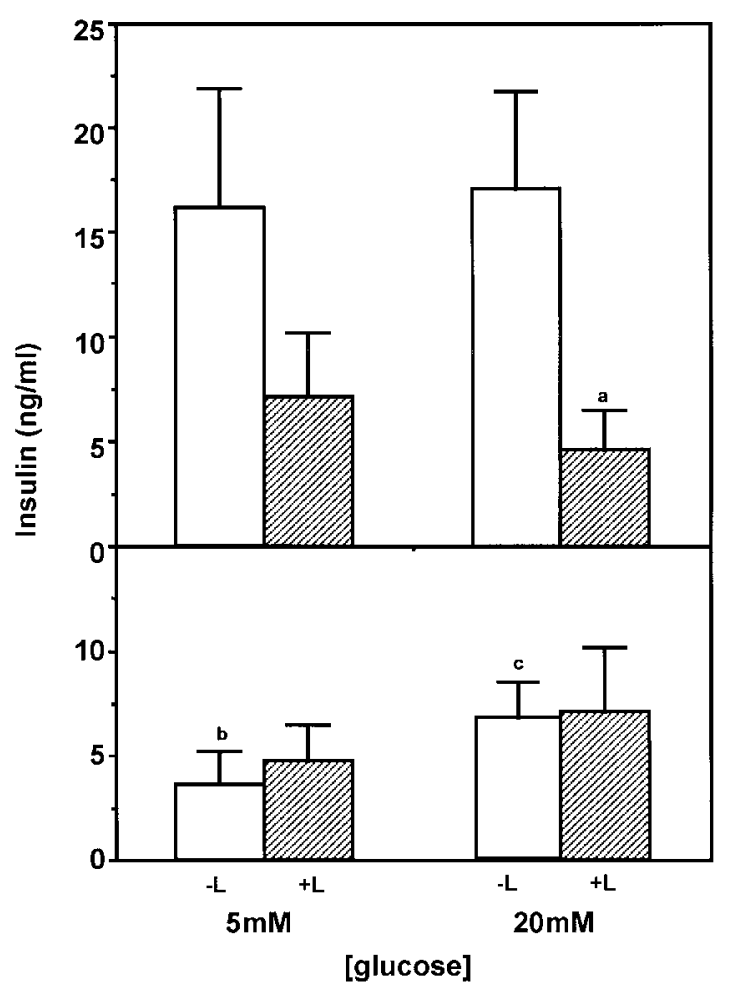

Figure 3 Basal insulin secretion (at $5 \mathrm{mmol} / \mathrm{l}$ glucose) and GSIS $(20 \mathrm{mmol} / \mathrm{l}$ glucose) from islets isolated from GLUC rats (upper panel) and AMOSE rats (lower panel) incubated with (shaded bars) and without (open bars) leptin $(100 \mathrm{ng} / \mathrm{ml})$ for $1 \mathrm{~h}$ at $37^{\circ} \mathrm{C}$. Results are means \pm S.E.M. of values obtained from islets isolated from five rats in each dietary group. Each incubation contained 20 islets in $1.0 \mathrm{ml}$ incubation medium and each point is the mean of five incubations. a: $P<0.05$ for the effect of leptin treatment. b: $P<0.05$ for differences between GLUC rats and AMOSE rats. c: $P<0.05$ for differences between insulin secretion at 5 and $20 \mathrm{mmol} / \mathrm{l}$ glucose. All other differences were not significant. 


\section{Discussion}

Feeding of a diet rich in high GI carbohydrate resulted in an increase in body weight as well as elevated plasma leptin, TG and NEFA levels. This was accompanied by an increased insulin response to glucose in vivo, with this hypersensitivity to glucose being maintained in isolated islets. In vivo, leptin was able to normalise this response. Leptin also inhibited insulin hypersecretion in vitro, showing that the effects of leptin on insulin secretion are direct effects on the islets. There was no effect of leptin on insulin secretion in the AMOSE rats, either in vivo or in vitro, suggesting that an effect of leptin is only seen when islet conditions predispose the islets to leptin action. In this study the level of hyperleptinaemia achieved in vivo was several fold higher than the fed endogenous levels and so it is not possible to say whether this effect would have been seen at more physiological leptin concentrations or whether the elevated fed level in GLUC rats was already attenuating insulin secretion in this model.

Dietary rodent models of insulin resistance, including high fat- and high fructose-fed rats exhibit impaired glucose tolerance as well as reduced glucose uptake during clamp studies (20-22). These animals may exhibit basal hyperinsulinaemia and the impaired glucose tolerance is accompanied by an elevated insulin response. In GLUC rats, there is no difference in glucose tolerance during an ivGTT or in glucose utilisation during clamp studies between low and high GI-fed rats (7). Thus the hypersecretion of insulin during an ivGTT in the GLUC rat does not appear to be due to the development of peripheral insulin resistance, but due to an enhanced sensitivity of the pancreas to glucose as confirmed in the in vitro studies. It is interesting that there was no transient hypoglycaemia following the exaggerated insulin response in the GLUC rats, suggesting that the duration of the insulin peak was too short to produce any measurable change in glucose or that the animals are mildly insulin resistant at physiological insulin levels.

GLUC rats exhibit postprandial hyperglycaemia but not fasting hyperglycaemia or elevated plasma glucose following an i.v. glucose load. Thus the hypersensitivity of islets from these rats to glucose appears to be due to exaggerated fluctuations in plasma glucose rather than to any chronic hyperglycaemia. The increased insulin secretion in this study is in contrast to that found with chronic hyperglycaemia where GSIS is suppressed in association with a reduction in GLUT 2 glucose transporters and a decreased activity of glucokinase (23).

Another possible mechanism for the changes in glucose sensitivity in the GLUC rats may be provided by the significantly elevated islet TG content. Both in vivo and in vitro studies have recognised the importance of fatty acids in the regulation of GSIS. In vivo, lowering of plasma NEFA levels in fasted rats prevents insulin secretion in response to glucose (24) and other secretagogues (25). In vitro, chronic fatty acid exposure has been reported to both inhibit and stimulate GSIS (26-28). Hyperinsulinaemia in vivo and GSIS in vitro have been shown to be highly correlated with the TG content of the pancreas (29). In the prediabetic phase of insulin hypersecretion in Zucker diabetic fatty (ZDF) rats, islet TG content is 5-10 times that of controls (26), similar to the levels found in the GLUC rats in this study. While all this evidence shows that an increase in fatty acid availability enhances insulin secretion, too much TG is toxic with $\beta$-cell failure being associated with a pancreatic TG content 50 times that of normal islets (30).

With the exception of those obese rodent models which lack functional leptin receptors in the pancreas ( $\mathrm{db} / \mathrm{db}$ mice and ZDF rats), in vivo acute and chronic studies have shown leptin-induced reductions in plasma insulin which are greater in obese animals than in lean animals $(16,17)$. Thus it appears that an effect of leptin on insulin secretion requires pancreatic TG stores which are both increased and accessible to leptin action. This was confirmed by a recent study in which the overexpression of leptin receptors in ZDF rats was accompanied by a reduction in TG stores (31) and restoration of GSIS (23). Leptin has been shown to alter fatty acid metabolism in the $\beta$-cell by depletion of TG stores $(32,33)$, increasing fatty acid oxidation (32) and increasing the expression of enzymes involved in fatty acid oxidation (34). Thus leptin's effects on GSIS may be due to its effects on islet lipid partitioning with the primary role of leptin in the $\beta$-cell being to prevent lipotoxicity. Leptin's effects on insulin secretion involve the activation of ATP-sensitive potassium channels (35). Long-chain acyl-CoA esters bind to and open these channels (36) and so the ability of leptin to alter insulin secretion may involve the formation of these long-chain acyl-CoA esters. Leptin has also been shown to inhibit the transcription of the preproinsulin gene (37) with this effect on insulin production involving different cellular pathways from those controlling insulin secretion.

Leptin production and secretion is regulated by insulin (38) with hyperinsulinaemia preceding or accompanying the development of hyperleptinaemia in different obesity models (39-41). The existence of an adipoinsular axis in which leptin regulates insulin production and secretion and insulin regulates leptin production and secretion has important implications for understanding the development of insulin resistance, obesity and type 2 diabetes in humans (38). The consumption of diets which cause a greater rise in postprandial insulin secretion may contribute to the development of obesity and hyperleptinaemia as seen in this study. High GI diets have also been shown to cause changes in lipid storage enzymes in adipose tissue which favour fat synthesis and deposition (4). Prolonged hyperleptinaemia in turn may lead to suppression of insulin secretion in an attempt to limit the size of these fat stores and 
subsequently the development of insulin resistance and diabetes. In a recent paper, Ferrannini et al. (42) established that more obese subjects are hyperinsulinaemic than are insulin-resistant suggesting that hypersecretion of insulin is not just a compensatory mechanism in response to peripheral insulin resistance but is a primary event in the development of obesity. Thus dietary strategies designed to reduce postprandial hyperinsulinaemia, i.e. diets in which the carbohydrate component consists mainly of low GI starches, could be important in the prevention of weight gain in humans.

\section{Acknowledgements}

This study was supported by a grant from the Diabetes Australia Research Trust.

\section{References}

1 Behall KM, Scholfield DJ, Yuhaniak I \& Canary J. Diets containing high amylose vs amylopectin starch: effects on metabolic variables in human subjects. American Journal of Clinical Nutrition $198949337-344$.

2 Higgins JA, Brand Miller JC \& Denyer GS. Development of insulin resistance in the rat is dependent on the rate of glucose absorption from the diet. Journal of Nutrition 1996126 596-602.

3 Kabir M, Rizkalla SW, Champ M, Luo J, Boillot J, Bruzzo JF et al. Dietary amylose-amylopectin starch content affects glucose and lipid metabolism in adipocytes of normal and diabetic rats. Journal of Nutrition 1998128 35-43.

4 Kabir M, Rizkalla SW, Ouignard-Boulange A, Guerre-Millo M, Boillot J, Ardouin B et al. A high glycemic index starch diet affects lipid storage-related enzymes in normal and to a lesser extent in diabetic rats. Journal of Nutrition 1998128 1878-1883.

5 Lerer-Metzger M, Rizkalla S, Luo J, Champ M, Kabir M, Bruzzo JF et al. Effects of long-term low-glycaemic index starchy food on plasma glucose and lipid concentrations and adipose tissue cellularity in normal and diabetic rats. British Journal of Nutrition $199675723-732$.

6 Kiens B \& Richter EA. Types of carbohydrate in an ordinary diet affect insulin action and muscle substrates in humans. American Journal of Clinical Nutrition 199663 47-53.

7 Denyer GS, Pawlak D, Higgins J, Widdup G, Bryson J, Caterson ID et al. Dietary carbohydrate and insulin resistance: lessons from humans and animals. Proceedings of the Nutrition Society of Australia 199822 158-167.

8 Emilsson V, Liu Y-L, Cawthorne MA, Morton NM \& Davenport M. Expression of the functional leptin receptor mRNA in pancreatic islets and direct inhibitory action of leptin on insulin secretion. Diabetes 199746 313-316.

9 Kieffer TJ, Heller RS \& Habener JF. Leptin receptors expressed on pancreatic $\beta$-cells. Biochemical and Biophysical Research Communications $1996224522-527$.

10 Poitout V, Rouault C, Guerre-Milo M, Briaud I \& Reach G. Inhibition of insulin secretion by leptin in normal rodent islets of Langerhans. Endocrinology $1998139822-826$.

11 Tanizawa Y, Okuya S, Ishihara H, Asano T, Yada T \& Oka Y. Direct stimulation of basal insulin secretion by physiological concentrations of leptin in pancreatic $\beta$ cells. Endocrinology 1997138 4513-4519.

12 Pallett AL, Morton NM, Cawthorne MA \& Emilsson V. Leptin inhibits insulin secretion and reduces insulin mRNA levels in rat isolated pancreatic islets. Biochemical and Biophysical Research Communications 1997238 267-270.
13 Roduit R \& Thorens B. Inhibition of glucose-induced insulin secretion by long term preexposure of pancreatic islets to leptin. FEBS Letters 1997415 179-182.

14 Leclercq-Meyer V \& Malaisse WJ. Failure of human and mouse leptin to affect insulin, glucagon and somatostatin secretion by the perfused rat pancreas at physiological glucose concentration. Molecular and Cellular Endocrinology 1998141 111-118.

15 Shimizu H, Ohtani K, Tsuchiya T, Takahashi H, Uehara Y, Sato N et al. Leptin stimulates insulin secretion and synthesis in HIT-T 15 cells. Peptides 199718 1263-1266.

16 Bryson JM, Phuyal JL, Swan V \& Caterson ID. Leptin has acute effects on glucose and lipid metabolism in both lean and gold thioglucose-obese mice. American Journal of Physiology 1999277 E417-E422.

17 Levin N, Nelson C, Gurney A, Vandlen R \& de Sauvage F. Decreased food intake does not completely account for adiposity reduction after ob protein infusion. PNAS 199693 1726-1730.

18 Sivitz WI, Walsh SA, Morgan DA, Thomas MJ \& Haynes WG. Effects of leptin on insulin sensitivity in normal rats. Endocrinology $19971383395-3401$.

19 Howell SL \& Taylor KW. Potassium ions and the secretion of insulin by islets of Langerhans incubated in vitro. Biochemical Journal 1968108 17-24.

20 Bryson JM, Cooney GJ, Wensley VR, Phuyal JL, Hew M, Denyer GS et al. High-fat feeding alters the response of rat PDH complex to acute changes in glucose and insulin. American Journal of Physiology 1995268 E752-E757.

21 Hara T, Cameron-Smith D, Cooney GJ, Kusunoki M, Tsutsumi K \& Storlien LH. The actions of a novel lipoprotein lipase activator, NO-1886, in hypertriglyceridemic fructose-fed rats. Metabolism $199847149-153$.

22 Storlien LH, Oakes ND, Pan DA, Kusunoki M \& Jenkins AB. Syndromes of insulin resistance in the rat. Inducement by diet and amelioration with Benfluorex. Diabetes $199342457-$ 462.

23 Wang M-Y, Koyama K, Shimabukuro M, Mangelsdorf D, Newgard CB \& Unger RH. Overexpression of leptin receptors in pancreatic islets of Zucker diabetic rats restores GLUT-2, glucokinase, and glucose-stimulated insulin secretion. PNAS $19989511921-11926$.

24 Stein DT, Esser V, Stevenson BE, Lane KE, Whiteside JH, Daniels $\mathrm{MB}$ et al. Essentiality of circulating fatty acids for glucose-stimulated insulin secretion in the fasted rat. Journal of Clinical Investigation $1996972728-2735$.

25 Dobbins RL, Chester MW, Stevenson BE, Daniels MB, Stein DT \& McGarry JD. A fatty acid-dependent step is critical for both glucose and non-glucose-stimulated insulin secretion. Journal of Clinical Investigation $19981012370-2376$.

26 Hirose H, Lee YH, Inman LR, Nagasawa Y, Johnson JH \& Unger RH. Defective fatty acid-mediated $\beta$-cell compensation in Zucker diabetic fatty rats. Journal of Biological Chemistry 1996271 5633-5637.

27 Liu YK Tornheim \& Leahy JL. Fatty acid-induced $\beta$-cell hypersensitivity to glucose. Journal of Clinical Investigation 1998 101 1870-1875.

28 Zhou Y-P \& Grill V. Long-term exposure of rat pancreatic islets to fatty acids inhibits glucose-induced insulin secretion and biosynthesis through a glucose fatty acid cycle. Journal of Clinical Investigation $199493870-876$.

29 Koyama K, Chen G, Lee Y \& Unger RH. Tissue triglycerides, insulin resistance, and insulin production: implications for hyperinsulinemia of obesity. American Journal of Physiology 1997 273 E708-E713.

30 Lee Y, Hirose H, Ohneda M, Johnson JH, McGarry JD \& Unger RH. $\beta$-cell lipotoxicity in the pathogenesis of non-insulin-dependent diabetes mellitus of obese rats: impairment in adipocyte- $\beta$-cell relationships. PNAS 199491 10878-10882.

31 Wang M-Y, Koyama K, Shimabukuro M, Newgard C \& Unger RH. $\mathrm{OB}-\mathrm{Rb}$ gene transfer to leptin-resistant islets reverses diabetogenic phenotype. PNAS $199895714-718$. 
32 Koyama K, Chen G, Wang M-Y, Lee Y, Shimabukuro M, Newgard $\mathrm{CB}$ et al. $\beta$-cell function in normal rats made chronically hyperleptinemic by adenovirus-leptin gene therapy. Diabetes 199746 1276-1280.

33 Shimabukuro M, Koyama K, Chen G, Wang MY, Trieu F, Lee N et al. Direct antidiabetic effect of leptin through triglyceride depletion of tissues. PNAS 199794 4637-4641.

34 Zhou YT, Shimabukuro M, Koyama K, Lee Y, Wang MY, Trieu F et al. Induction by leptin of uncoupling protein-2 and enzymes of fatty acid oxidation. PNAS 199794 6386-6390.

35 Kieffer TJ, Heller RS, Leech CA, Holz GG \& Habener JF. Leptin suppression of insulin secretion by the activation of ATPsensitive $\mathrm{K}^{+}$channels in pancreatic $\beta$-cells. Diabetes 199746 1087-1093.

36 Branstrom R, Corkey BE, Berggren PO \& Larsson O. Evidence for a unique long chain acyl-CoA ester binding site on the ATP-regulated potassium channel in mouse pancreatic beta cells. Journal of Biological Chemistry 1997272 1739017394.

37 Seufert J, Kieffer TJ \& Habener JF. Leptin inhibits insulin gene transcription and reverses hyperinsulinemia in leptin-deficient ob/ob mice. PNAS 199996 674-679.
38 Kieffer TJ \& Habener JF. The adipoinsular axis: effects of leptin on pancreatic $\beta$-cells. American Journal of Physiology 2000278 E1-E14.

39 Cusin I, Sainsbury A, Doyle P, Rohner-Jeanrenaud F \& Jeanrenaud B. The $o b$ gene and insulin. A relationship leading to clues to the understanding of obesity. Diabetes 199544 1467-1470.

40 Bryson JM, Phuyal JL, Proctor DR, Blair SC, Caterson ID \& Cooney GJ. Plasma insulin rise precedes rise in ob mRNA expression and plasma leptin in gold thioglucose-obese mice. American Journal of Physiology 1999276 E358-E364.

41 Hotta K, Gustafson TA, Ortmeyer HK, Bodkin NL, Nicolson MA \& Hansen BC. Regulation of obese (ob) mRNA and plasma leptin levels in Rhesus monkeys. Journal of Biological Chemistry 1996 $27125327-25331$

42 Ferrannini E, Natali A, Bell P, Cavallo-Perin P, Lalic N \& Mingrone G, on behalf of the European Group for the Study of Insulin Resistance (EGIR). Insulin resistance and hypersecretion in obesity. Journal of Clinical Investigation 1997100 1166-1173.

Received 1 March 2000

Accepted 12 May 2000 